\title{
" The Limits of Global Liberalisation: Lessons from Asia and Latin America"
}

Richard Higgott and Nicola Phillips

CSGR Working Paper No. 22/ 98

January 1999
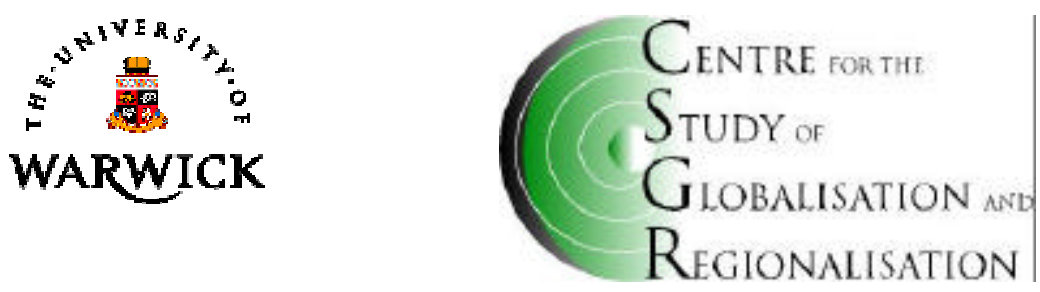

E.S.R.C
ECONOMIC
\&SOCIAL
RESEARCH
COUNCIL

Centre for the Study of G Iobalisation and Regionalisation (CSG R), University of Warwick, Coventry CV4 7AL, United-Kingdom. URL: http://www.warwick.ac.uk/fac/soc/CSGR 
The Limits of Global Liberalisation: Lessons from Asia and Latin America

Richard Higgott and Nicola Phillips ${ }^{1}$

University of Warwick, CSGR, and D epartment of Politics and International Studies

CSG R Working Paper No. 22/ 98

January 1999

\begin{abstract}
:
We are in the midst of a series of economic crises that have altered the economic and socio-political fortunes of several heretofore rapidly developing states. At a second, more abstract though no less significant level, the East Asian economic crises and the global contagion that has emanated from them represent a set-back for the inexorable process of international economic liberalisation that has come to be known as 'globalisation'. On the eve of the twentyfirst century we are experiencing the first serious challenges to the hegemony of neoliberalism as the dominant form of economic organisation since the end of the Cold War. This resistance is not uniform, nor is it restricted to one site or group of actors. Moreover, in many instances, resistance is often to practice more than to principle. Events in Asia and Latin America represent less the final ideological triumph of liberalism in a post-Cold War era rather than a context for rethinking the significant aspects of the neoliberal project. The aim of this paper, embedded in a comparative discussion of the initial economic crises in East Asia with unfolding events in Latin America, is to make some judgements about the broader implications for the potential management of the global economic order at the end of the twentieth century.
\end{abstract}

Keywords: Global liberalisation, crises of globalisation, free market fundamentalism, policy reform, regional projects.

Address for correspondence:

Nicola Phillips

Department of Politics and International Studies

University of Warwick

Coventry, CV4 7AL, UK.

\footnotetext{
${ }^{1}$ Richard Higgott is Professor of International Political Economy at the University of Warwick and Director of the ESRC Centre for the Study of Globalisation and Regionalisation. He is editor of The Pacific Review.

Richard.Higgott@warwick.ac.uk

Dr Nicola Phillips is Lecturer in Politics and International Studies at the University of Warwick.

N.J.Phillips@warwick.ac.uk
} 
"It is impossible to say if the next phase of capitalist ideology will prove more or less successful than the market fundamentalism it displaces. What is certain is that the era of laisser-faire ideology is fading. Capitalism's own incomparable instinct for self preservation will see to that. ${ }^{\text {" }}$

\section{Introduction}

For the last decade, the progressive deregulation of financial markets has occurred at breakneck speed. The triumph of the West over state-controlled collectivism in the Soviet empire during the Cold War gave way to Fukuyama's 'end of history'2 and, following the first wave of the Asian economic crisis of late 1997, the Anglo-American economic model was deemed to have triumphed over the rival Asian developmental statist model. Similarly, Europe was languishing economically and the Asian 'meltdown' appeared containable within the region. Triumphalism in the US and in the pages of liberal magazines such as The Economist was difficult to disguise. ${ }^{3}$

Indeed, for many in 'the West' the hubris of the 'Asian way' was getting its comeuppance. US policy makers -- such as United States Trade Representative Charlene Barshevsky, Under-Secretary of State for Commerce Jeffrey Garten, Treasury Secretary Robert Rubin, Under-Secretary Larry Summers and other members of what Jagdish Bhagwati calls the 'Wall Street-Treasury Complex' -- initially saw the Asian crisis as a 'window of opportunity' for the US. ${ }^{4}$ In less particularist terms, Michel Camdessus, managing director of the IMF, saw the Asian crisis as a 'blessing in disguise' that would sweep away crony capitalism and free up markets along 'western' lines.

\footnotetext{
1 Anatole Kaletsky, 'Farewell Laisser-Faire', The Times, 10 September 1998, p. 22.

2 Frances Fukuyama, The End of History and the Last Man, (New York: Free Press, 1992).

3 Nowhere is this better exemplified than in Mortimer Zuckerman's euphoric 'A Second American Century', Foreign Affairs, 77 (3) 1998: 18-31.

4 For a discussion see Waldon Bello, 'East Asia on the Eve of the Great Transformation', International Political Economy, 5 (3) 1998, pp. 33-36.
} 
The neoliberal approach to globalisation seemed everywhere predominant. But in the subsequent 12 months, especially following Russia's economic collapse in early September 1998, popular punditry Economist style was predicting a global rather than regional meltdown. Western analysts, becoming increasingly conscious of their own hubris, now offer predictions ranging from a severe recession in the OECD countries through to expectations of a 1930s-style great depression. More generally, it is argued in even the most staid of chronicles that the events of 1998 represent '...a historic setback to the advance of Western style capitalism'. ${ }^{5}$ The window of opportunity has closed and the first real backlash against globalisation is now fully in train. At the very least, US and IMF dreams of 12 months ago of even more open capital markets have been put on the back burner, replaced by fears that the anti-globalisation sentiments now strong in many emerging markets and growing the USA, could spread to other liberalised OECD countries. ${ }^{6}$ In effect, what we are witnessing is the first post-Cold War 'crisis of globalisation'.

Now, 'globalisation' is a slippery and fast moving concept. It is also a contested concept that cannot be detailed here save to note that we are in a 'third stage' of the debate over its nature and impact. ${ }^{7}$ Phase one saw globalisation as pervasive, with the traditional actor in international economic and political orders -- the nation-state -being reduced to the status of a powerless residual category in the face of global imperatives for greater economic liberalisation. ${ }^{8}$ Phase two saw a backlash. Little had really changed. Globalisation was but hyperbole and myth. ${ }^{9}$ Phase three in our

5 Paul Blustein, 'Financial Crisis May Stall Capitalism's Global March', International Herald Tribune, 7 September 1998, p. 13.

6 Gary Burtless, Robert Z. Lawrence, Robert E. Litan and Robert J. Shapiro, Globaphobia: Confronting Fears About Open Trade, (Washington: Brookings, 1998).

7 See Colin Hay and David Marsh, 'Introduction' in Hay and Marsh (eds.) Demystifying Globalisation, (Basingstoke: Macmillan, 1998). There is now a voluminous body of literature that we might call 'globalisation studies.' For an attempt to provide some taxonomic order to it see Richard Higgott and Simon Reich, 'Globalisation and Sites of Conflict: Towards Definition and Taxonomy, Working Paper, No. 1, (Warwick University, ESRC Centre for the Study of Globalisation and Regionalisation, 1998)

8 Cf. Kenichi Ohmae, The Borderless World: Power and Strategy in the Interlinked Economy, (New York: Fontana, 1990).

${ }^{9}$ Cf. Paul Hirst and Grahame Thompson, Globalisation in Question: The International Economy and the Possibilities of Governance, (Cambridge: Polity, 1996). 
understanding reflects a greater nuance and complexity. There is indeed something different that distinguishes the contemporary era from previous ones. Globalisation needs to be understood as a multi-faceted process that is both material (real) across the economic domains and ideational (offering competing normative discourses of knowledge of how the global economic and political orders might function). But this is a developing, contingent and, as events in the global economy since the second half of 1997 attest, by no means irreversible process.

Thus the aim of this paper, embedded in a comparative discussion of the initial economic crises in East Asia with unfolding events in Latin America, is to make some judgements about the broader implications for the potential management of the global economic order at the end of the twentieth century. The advantage of this comparative method is two-fold. Firstly, it allows us to argue the generalisable nature of many of the more significant trends in train in the contemporary economic order, particularly with regard to the impact of footloose capital on emerging markets. Secondly, and by no means in contradiction of the previous claim, it allows us also to highlight the importance of unique historical geographical and political experience and both the similarities and differences in impact that these experiences have on policy responses in different regions. Generalisation, the hallmark of theorising, is grounded in sound empirical analysis.

Section one of the paper draws out the general characteristics of the crisis of globalisation. It focus specifically on the international market-driven (as opposed to endogenous state-induced) aspects of the crisis. We demonstrate the limits of liberal capitalism in its more fundamentalist (free market) form. We argue, in contrast to most neo-classical economic theory, that it is no longer possible to ignore the fact that financial capital plays as much a political role as an economic one in the structuring of the global order. To be specific, the post Bretton Woods era of deregulated exchange rates and an increasingly liberalised market structure has assisted in the maintenance of a near US economic hegemony, notwithstanding the USA's own deteriorating economic position when seen as a share of gross world product. US financial actors -- 
public and private, domestic and international -- have remained the key players in an era increasingly dominated by private capital flows. ${ }^{10}$

Nowhere is the preceding point better illustrated than in the manipulation by the US of transnational regulatory authority, via the IMF involvement in the policy responses to Asian crisis. This is discussed in some detail in section two of the paper which focuses in comparative fashion on Asian and Latin American responses to the crisis. The first element of this discussion focuses on the rethinking of international policy reform at the national level in Asia and Latin America, with particular reference to the interactions between national governments and international financial institutions. The second element concerns the potential for articulation of more closely defined regional agendas and identities in the longer term. In this context, global, regional and national processes should be seen as dialectically related rather than as discrete phenomena.

In section three, we consider some of the likely longer term Asian and Latin America responses to the intervention of the international financial institutions in the context of the debate over the prospects for continued global economic liberalisation on the one hand versus some form of re-regulation of international capital on the other. We demonstrate the tension between dominant Anglo-American understandings of global liberalisation on the one hand and the emergence of East Asian and Latin American sites of resistance to some aspects of it (both intellectual and practical) on the other. We do not suggest that responses from the two regions are identical -- history and geography matter -- but we do suggest that these respective responses pose questions for how the Anglo-American model will be tested in the next century. We make some judgements about the nature of global economic management and specifically the necessary role of regions in that process of management for the twenty-first century.

\footnotetext{
10 See Eric Helleiner, States and the Reemergence of Global Finance (Ithaca: Cornell, 1994) and the discussion of how states become 'just one source of authority among several' in Susan Strange's The Retreat of the State: The Diffusion of World Power in the World Economy, (Cambridge: Cambridge University Press, 1996), p. 73.
} 
We should also explain at this stage what this paper is not. It is not a paper about the causes of the Asian economic crises (note plural). Explanations are numerous and varied. ${ }^{11}$ Rather we are concerned with two broader issues: first, the ideological struggle over the nature of free-market versus other variants of capitalism; and second, the issue of the intellectual hegemony of neo-classical economic rationality and its concomitant assumptions about the limited explanatory role of governance (as opposed to government) in neo-classical thought. It is our argument that the events in East Asia and their subsequent global aftermath represent, at two levels, the first "crisis of globalisation'.

At an obvious first level, we are in the midst of a series of economic crises that have altered the economic and socio-political fortunes of several heretofore rapidly developing states. At a second, more abstract though no less significant level, the East Asian economic crises and the global contagion that has emanated from them represent a set-back for the inexorable process of international economic liberalisation that has come to be known as 'globalisation'. On the eve of the twenty-first century we are experiencing the first serious challenges to the hegemony of neoliberalism as the dominant form of economic organisation since the end of the Cold War. This resistance is not uniform, nor is it restricted to one site or group of actors. Moreover, in many instances, resistance is often to practice more than to principle. Events in Asia represent less the final ideological triumph of liberalism in a post-Cold War era rather than a context for rethinking the significant aspects of the neoliberal project in Asia and elsewhere.

\section{(1) The 'Crisis of Globalisation' and the Limits of Neoliberalism}

The crisis of globalisation, while caused by spreading currency and economic crises and increasingly volatile stock market activity, is not about these immediate phenomena. Stock markets will rise and fall in the future as they have done in the past.

\footnotetext{
${ }^{11}$ For a review of competing explanations see Richard Higgott, 'The Asian Economic Crisis: A Study
} 
What the crisis of globalisation is about is much more fundamental. It is about the prospects for the continued hegemony of liberal capitalism. What was assumed twelve months ago -- that free market capitalism had routed all alternative forms of economic organisation -- is now called into question, even by some of its leading exponents. By way of example, and most shocking of all for neo-classical purists, one of their own, Paul Krugman, has recently called for the introduction of exchange controls (albeit temporary in nature) -- and in the pages of Fortune magazine no less. The debate over the rectitude of this policy (and many question it) is less important than what it symbolises. In essence what Krugman has suggested is that a suspension of market forces to allow governments the breathing space to 'sort things out' in Asia might be necessary. ${ }^{12}$ In so doing, he has contributed to the opening up of the policy space that not long ago was firmly under the hegemony of a neoliberal disposition towards globalisation. Similar debates have taken root in Latin America, first in response to the Mexican peso crisis of December 1994, but much more concretely in the light of the Asian and present global crises.

As the globalisation backlash gathers momentum, this policy space has expanded along a continuum from the once hegemonic neoliberal discourse, across the social democratic terrain towards a reconstituted Keynesianism and even back towards Marxism which, in the 150th year of the publication of the Communist Manifesto, has adherents keen to point out -- once again -- that capitalism may have reached its last (global) crisis. This is intellectually interesting speculation, but probably premature. What we are seeing is not a crisis of capitalism as much as a crisis of free market fundamentalism. Moreover, the crisis that we are witnessing is less an economic one than one of governance, or more specifically the absence of international economic institutional governance since the time of the collapse of Bretton Woods and the US's systematic neglect of the dollar over the last several decades. The desire to let the dollar run free has been at the root of the deregulation of the international financial

in the Politics of Resentment', New Political Economy, 3 (3) 1998: 333-55.

12 Paul Krugman, 'Saving Asia: It's Time to Get Radical', Fortune, 7 September 1998, pp. 33-37. For a counter-argument, see 'The Case for Global Finance', The Economist, 12 September 1998, pp. 1920. 
system over the last decade which, along with technological advances in the way we move around the globe, has brought us the hedge fund, pegged exchange rates and the subsequent currency crises that started in East Asia in 1997.

This is all very frustrating for global liberalisers. In the period between the end of the Cold War and the onset of the Asian crisis, the argument for liberalisation and open markets as generators of wealth appeared to have been won at both intellectual and evidentiary levels. Between 1950 and 1996 the volume of world output rose 6-fold, world merchandise trade expanded 16-fold, output of manufactures grew 9-fold and trade in manufactures grew 31 -fold. ${ }^{13}$ The commitment to economic liberalisation had spread geographically from Europe and North America and in the late twentieth century to other parts of the world, notably (notwithstanding recent crises) to East Asia, other parts of the Americas and, since the end of the Cold War, to East and Central Europe and China. Experiments with import substitution and protectionism had been progressively abandoned by those states (notably in Latin America) that once pursued them. The assumption that open trade benefited consumers and protection dulled incentives for innovation had become largely uncontested.

So what have we learned from the spread of the Asian crisis? Firstly, markets are too important as social institutions to be left in the hands of free marketeers. Few if any of those who espouse the values of the market are sensitive to the manner in which they are social constructs. Political scientists have been aware of this for ages and indeed economics, in its earlier incarnations as political economy, was too. ${ }^{14}$ Developments in the discipline of economics since the second world war, notwithstanding the writings of Karl Polanyi, have done much to remove any appreciation of the historical development and social embeddedness of markets. ${ }^{15}$ If nothing else, the current crisis

\footnotetext{
13 Financial Times, 18 May 1998, p. 4.

14 Sources to be added. Katzenstein 1978, Caporaso \& Levine 1992.

15 See Karl Polanyi, The Great Transformation: The Political and Economic Origins of our Time, (Boston, Beacon Press, 1944) and latter day interpreters such as John Ruggie, 'International Regimes, Trransactions and Change: Embedded Liberalism in the Post War Economic Order', International Organization, 36 (2) 1982: 379-415.
} 
should put paid to the more extreme versions of free market fundamentalism with its emphasis on the unfettered movement in and out of small to medium sized economies of highly leveraged dollar liquidity. This is but one facet of contemporary capitalism, not capitalism per se.

Thus, the crisis has brought home to us -- or should have done -- the indispensable role of political (and indeed social) institutions as necessary stable locations within which markets can operate. This position is demonstrated counterfactually by noting the impact of the absence of controls on the events of 1998 and the now subsequent recognition -- even in the Wall Street-Treasury corridor -- that such funds should be regulated and supervised. The tide is turning against those who argue that controls on short term capital movements should be resisted. This is the case intellectually (viz. the views of Paul Krugman) and empirically, as can be seen in Asia, most provocatively in Malaysia, but also in the more sensible discussions that are emerging about the possibility of developing regional financial managerial institutions.

These arguments are particularly common with reference to the Latin American region. The Brazilians and others now assert that regional states have the sovereign right to protect themselves against capital flight, taking note of the long-standing Chilean policy of maintaining restrictions on short-term capital inflows (although paradoxically these have recently been softened). Regional institutions like the UN Economic Commission for Latin America highlight the positive effects of capital restrictions in reducing vulnerability to external exchange crises and inclinations towards policies which result in overvaluing the currency, with obvious knock-on effects for the health of current accounts and export sectors. ${ }^{16}$ Indeed, even in Washington there is a grudging acknowledgement that this might be a legitimate short run course of action in times of severe financial crisis. 
The second and related 'lesson' from the Asian crisis is that economic stability and political consent are not achieved in processes discrete from one another. Governments now, perhaps more than ever, have a role in managing macroeconomic demand and the political implications that flow from differing management strategies. Whether the Asian crisis was caused by crony capitalism at home or entrepreneurial capitalism 'run amok', it and its repercussions in other regions of the world have led to a questioning of liberalisation and globalisation in general and the wisdom of unregulated global financial markets in particular. The big question for the twenty-first century is whether we should try to put the footloose financial genie back in the bottle, and if so how. A consensus may well emerge that some way of disciplining financial market agents as well as the affected countries must be found. New adherents to liberal capitalism in the emerging markets have been badly bruised in the recent market turmoils and, as a consequence, the credibility of, and faith in, the international financial system as an efficient allocator of capital has been badly eroded.

This is not yet the case in the large developed economies. While the purist free market position may be asserted with less ideological fervour now than several years ago, it remains an article of faith in the policy communities and in most of the scholarly economics community of the western world. The real problem, they argue, is to be found in the flawed banking systems of the emerging markets, not in the workings of the international capital markets. This is illustrated, for example, by the observation that the Chilean financial system was significantly more 'open' than those of the Asian 'ex-tigers' before the onset of the Asian currency crises, at least in institutional terms. Only a very small percentage of bank lending in the 1990s in the Asian countries related to the activities of foreign-owned banks, whereas Chile has no restrictions on foreign access to ownership. Thus the difference with Chile related to the structures of the financial sector, while its restrictions on capital flows amounted only to the levels maintained in the United States. ${ }^{17}$ Crucially for this sort of defence, furthermore, the countries worst affected by the crises are those which either have adopted only a

16 UN Economic Commission for Latin America and the Caribbean (ECLAC), The Impact of the Asian Crisis on Latin America (Santiago de Chile, May 1998), p. 39.

17 'Two Kinds of Openness', The Economist, 12 September 1998, p. 106. 
lukewarm variant of the Washington consensus, or else those in which macreconomic desequilibria (such as overvaluations of the currency and high fiscal deficits) were most pronounced. Hence, runs the argument, it comes as no surprise that in Latin America Venezuela and Brazil should be the countries most threatened with economic collapse.

Even if the above arguments were accurate, developing country analysts and practitioners still (correctly in our minds) assert that the market responses of the last 12 months have been out of all proportion to economic realities on the ground in almost all the most badly hit countries (with the possible exception of Indonesia). ${ }^{18}$ However, it is notable that the Brazilian stock market has fallen (in percentage terms) by slightly more than its Indonesian counterpart (46\% and $45 \%$ respectively since the onset of the Asian crises), but Brazil has not yet experienced a similar currency collapse and economic crisis despite a vastly overvalued real and burgeoning fiscal deficit. If the optimism that generated the high inflows of capital to the region was excessive, then so too has been the market panic that saw the process reversed in a few short months. Those international investors who thought the East Asian NIEs could do no wrong until early 1997 appeared, after that date, to think they could do nothing right. The sense of deception spreads also to Latin America: these, after all, were policies that markets were supposed to approve of, and Latin American countries for the most part have been near paragons of virtue. ${ }^{19}$ Apparently, Latin Americans observe, this was just a short-lived marriage of convenience. How, Asians ask, can they lose favour quite so suddenly?

The answers are as much psychological and political as they are economic. Individual investor rationality has clearly resulted in collective irrationality. Contagion in the market place has not been the fault of the Asians. Nor was it new, but the big difference with shocks in the era of the gold standard between 1870 and 1914 is that

\footnotetext{
18 See Richard Robison and Andrew Rosser, 'Contesting Reform: Indonesia's New Order and the IMF' World Development, 1998, forthcoming.

19 Stephen Fidler, Jonathan Wheatley and Ken Warn, 'Continent in Crisis', Financial Times, 12/13 September 1998.
} 
modern technology accelerates transmission speeds for capital transfers and, as a consequence, increases the potential for panic and herd-like destabilisation in the market place. Panic, in the words of Robert Wade borrowing from cognitive psychology, brings about a Gestalt shift 'from Miracle Asia to Crony Asia'. The shift is immediate and total and firmly situates market 'panic' as the most salient explanation of the crisis. ${ }^{20}$

Size also matters. In sharp contrast to earlier periods, the volumes of capital flows are massively inflated by leveraged borrowing. The world in the 1990s was literally awash with vast amounts of money speculatively seeking high, short term returns in the markets of small to medium size countries the domestic money markets of which have now proved incapable of coping with the shocks that can be delivered by the international financial markets. ${ }^{21}$ Between 1990 and 1996, the developing countries' share of total world FDI increased from $14.9 \%$ to $37.8 \%$. Of the total directed to developing countries, $63 \%$ was directed to Asia and $31 \%$ to Latin America and the Caribbean. ${ }^{22}$ In 1994, Argentina was the third largest recipient of FDI worldwide. For 1995, net flows to Argentina alone reached nearly US\$4 billion, and in 1997 the total for the Latin American region reached some $\$ 80$ billion for the first six months (before the Asian crises). ${ }^{23}$ Between 1994 and 1996 net private inflows into Indonesia, Korea, Malaysia, Thailand and the Philippines grew from US $\$ 48$ billion to US\$93 billion. The figure for 1997 was minus US\$12 billion. ${ }^{24}$

The wider point about the last 12 months since the beginning of the Asian currency crises is that we have gone from one of seeing it as a contained, and containable

20 Robert Wade, 'Gestalt Shift: From "Miracle" to "Cronyism" in the Asia Crisis', Cambridge Journal of Economics, forthcoming, 1998.

21 At the height of the Thai currency crisis in 1997 one hedge fund had a short term loan equal to 20 percent of the countries official reserves. John Plender, 'Revisiting a Deadly Disease', Financial Times, 21 September 1998.

22 UN Economic Commission for Latin America and the Caribbean (ECLAC), Foreign Direct Investment in Latin America and the Caribbean, 1997 Report (Santiago de Chile).

23 UN Economic Commission for Latin America and the Caribbean (ECLAC), Economic Survey of Latin America and the Caribbean 1997-1998 (Santiago de Chile, September 1998). Interestingly, though, some two-thirds of these capital flows comprised long-term direct investment.

${ }^{24}$ Financial Times, 16 February 1998, p. 21 
regional economic problem to one that, since the collapse of the Russian economy and its growing hold in Latin America, now threatens the basis of much economic theory. It is for this reason that the current global economic crisis is also an intellectual crisis for advocates of the Anglo-American model of laissez-faire capitalism. Its hour of triumph is turning out to be its nightmare. Perhaps the very strength of liberal economic theory is also its major weakness. Its concentration on openness and growth at the expense of non economic, especially socio-political, factors has lead to a parsimony of theorising in economics that no other social science -- as they are frequently told -- can match. This theoretical parsimony has parallels in practice, the effect of which is to minimise the salience of all other factors and make economics analytically insensitive to much of the complex and combative politics that constitutes the down side of economic liberalisation.

At this current juncture we have a serious political problem and, because of the limitations of contemporary economic analysis, a lacunae in our theoretical ability to deal with it. The problem is what some authors now see as the growth of

'wild west capitalism and uncivil society. Here's the irony: It is not the spectre of Marx that hovers over capitalism; it is "robber capitalism" that rots the cross of free market economics from Moscow to Bangkok. ... Lawlessness in exercising free market principles permeates the virtual global economy' and financial markets. ${ }^{25}$

Money laundering, mafias, drug barons and arms traders all contribute to the making of 'uncivil society'. ${ }^{26}$ They are expanding at an unprecedented rate and neither the policy communities in the domestic or the international institutional arenas appreciate their influence or have the ability to police them.

As analysts, we understand that the integration of the international economy -especially demand for goods, capital and services -- is a strong secular tendency in the

25 Suchada Kulawat, 'Capitalism: A tale of suspense', Bangkok Post, 28 August 1998, p. 8.

26 Strange, The Retreat of the State and Mad Money (Manchester: Manchester University Press, 1998) especially chapter 7. 
contemporary era. That these demands have changed the traditional economic practices of many societies is also well understood. At its strongest, a liberal globalisation thesis -- the essence of the Anglo-American model of capitalist development -- argues there has been a shift in the relationship between state authority and market power. The increase in capital mobility -- arising from financial deregulation and revolutions in technology and communication -- has meant that governments have shifted the cost of the welfare state from capital to the recipients in order to prevent capital exercising exit options offered by the deregulation process. ${ }^{27}$ The urge for free markets and small government has created asymmetries in the relationship between the global economy and the national state that in the developed world has undermined John Ruggie's 'embedded liberal compromise';28 and this is a compromise that had little or no purchase in most, if not all, emerging markets.

These conditions appear to have been tolerated in emerging markets while they were undergoing periods of rapid economic growth (especially in the early 1990s) and while there were few or no articulate voices within their weak or demobilised civil societies to argue strongly for the kinds of domestic compensatory mechanisms we have come to expect in the advanced western democracies. Ironically, one of the paradoxes of the global financial crisis is that voices capable and willing to articulate objections to the adverse effects of global liberalisation appear to becoming increasingly strident. As we will argue in the next section, this has important political and theoretical implications for the continuance of the liberalisation process. When pursued in the absence of the adequate provision of compensatory domestic welfare (as is the case in most emerging markets) the free market liberalisation of trade and finance ceases to be simply sound economic theory. It also becomes contentious political practice. Rather than being recognised as welfare-enhancing overall, it is seen as having negative redistributive consequences that disturb prevailing social structures and exacerbate resistance to

27 For an empirical discussion of how direct taxes on capital have declined in the major economies since the 1980s see Daniel Rodrik, Has International Economic Integration Gone Too Far? (Institute for International Economics, 1997), pp. 85-89. Page numbers are from a mimeod manuscript.

28 See John Gerard Ruggie, 'At Home Abroad, Abroad at Home: International Liberalisation and Domestic Stability in the New World Economy, Millennium: Journal of International Studies, 24 (3) 1995: 507-26. 
globalisation (defined here as greater international economic integration) by the dispossessed or disadvantaged.

The standard neo-classical economic response -- that globalisation enhances aggregate welfare overall -- might well be correct, but irrelevant. Good economic theory can be poor political theory. Increasingly articulate NGOs voice objections to the side effects of unfettered liberalisation. They are not driven simply by protectionist desires of narrow interest groups. Rather they exhibit genuine concerns about the disintegrative effects of liberalisation. Communities attach value to means as well as ends. Even where the material compensatory mechanisms are adequate, the destruction of domestic social arrangements can still have deleterious political outcomes. Liberalisation at the domestic level provided the necessary foundations for the construction of a globalised world economy, and now is pivotal for the maintenance of its policy-based underpinnings. But securing domestic political support for the continued liberalisation of domestic economies and of the global economy requires more than just the assertion of its economic virtue. While that virtue remains largely unquestioned in the policy making communities of the developed world, it is not treated as axiomatic in much of the developing world, especially since the onset of the Asian economic crisis of 1997. If the benefits of the rapid economic growth of the last several decades are not to be jeopardised, then how social cohesion is maintained in the face of liberalisation will become a major question for governments and international institutions. This is something we return to in the last section of the paper.

Thus, although a rapid aggregate increase in global wealth and production has occurred over the last several decades, it has been accompanied by a corresponding political and social naiveté as to the effects of these processes on the civil polities of developed and developing societies alike. From a neo-classical economic perspective, government -- especially the welfare state in the post world war two era -- is inefficient. Thus, beyond the provision of basic public goods (the rule of law and external security), the dismantling of the public economy must come sooner or later in 
an era of globalisation. This argument is at the root of 'western' objections to the Asian developmental statist model.

But much economic analysis fails to recognise the manner in which domestic political institutions have assets capable of mediating the effect of global economic activity -for better or worse -- in their own territorial space. While the debate in the international institutions in the 1990s has focused more on the question of good governance $^{29}$, it has done so largely with a limited neo-classical economic and neoliberal political 'night watchman' view of the state. There is still an unwillingness in the international policy community to recognise the manner in which markets are socio-political constructions, that their domestic functioning depends on their legitimacy and support within civil society and that the welfare state might be important for the stability of an open international economy.

This myopia is, to say the least, unfortunate. Unlike Polanyi's reading of the nineteenth century, much modern economic analysis ignores the degree to which domestic compensation -- Ruggie's embedded liberal compromise -- has been an important factor in enhancing international openness and political stability. It helped to mitigate the tensions inherent in the relationship between capitalism as a system of economic production and exchange on the one hand and democracy as a process of legitimation of this system on the other. The problem with the neoliberal agenda is that economic liberalisation often becomes an end in itself. Little consideration is given to its effect on prevailing social norms and values within societies and polities. It is for this reason that the orthodox economic theory that has prevailed in the major international institutions and in the foreign policy establishments of the major western powers has had little patience for what it sees as the essentially negative dimensions of so-called 'Asian values'. And indeed, the effects on those Asian states in economic crisis is seen to

29 See especially the World Bank's World Development Report 1997: The State in a Changing World (New York: Oxford University Press) and The East Asian Miracle: Economic Growth and Public Policy (New York: Oxford University Press, 1993). 
provide proof positive of the superior virtues of a neoliberal approach to market organisation.

But this is to take the wrong message from what has happened in East Asia. The case can also be made that it was not the involvement of the state in the economy per se that was the source of the crisis, rather than that it was the nature of the involvement of the state that was to blame. Moreover, it would be a mistake to assume that the transformative capacity of the developmental state in Asia has passed its sell-by date. The issue for the future is how this capacity might be recomposed in a meaningful problem-solving fashion. In contrast to a strong globalisation thesis of the neoliberal genre, the state is not, pace Kenichi Ohmae, 'dead', nor even, pace Susan Strange, in retreat on all fronts. ${ }^{30}$ There is still no substitute for the state as the repository of sovereignty and rule-making and as provider of national security. It is also the socialiser of risk of last resort and the orchestrator of co-ordinated policy responses to the challenges thrown up by the processes of globalisation. Successful politics can build state capability in the face of change. The future task is to analyse the national state as in a 'process of adaptation', not decline. ${ }^{31}$ This will be a more, not less, complex task over time. Once we move beyond the assumptions of the neoliberal convergence hypothesis popular across the ideological spectrum, ${ }^{32}$ differences in national (and regional) responses to globalisation, and the state capacities which drive these responses, will become apparent. ${ }^{33}$ In the section that follows, we try to address some of these issues in a comparative discussion of East Asia and Latin America.

\section{(2) Asian and Latin American Windows on Global Liberalisation: Into the Crises}

30 Kenichi Ohmae, The End of the Nation State: The Rise of Regional Economies, (New York: Free Press, 1995) and Strange, The Retreat of the State.

31 See Linda Weiss, The Myth of the Powerless State, (Ithaca: Cornell, 1998).

32 Compare the similar analytical, albeit different normative, views of neo-classical economist Jagdish Bhagwati , 'The Capital Myth: The Difference Between Trade in Widgets and Trade in Dollars', Foreign Affairs, 77 (3) 1998 and neo-Gramscian political economist Stephen Gill, 'Globalisation, Market Civilisation and Disciplinary Neoliberalism', Millennium: Journal of International Studies, 24 (3) 1995: 399-423. 
Clearly the cases of Asia and Latin America differ from each other in many respects. The most basic difference is that Latin American countries, this time, are suffering as a result of the global turmoil unleashed by the currency and economic collapses in Asia. As such, Latin American difficulties can be traced to repercussive events or to the contagion effect which are more or less exacerbated by the condition of the individual national economies. The second difference, however, leads in interesting directions concerning more general questions about competing forms of capitalism and responses to the crises of global liberalisation. Latin American neoliberalism has always conformed more closely to the Anglo-American model of global capitalism than its equivalent in the Asian region. There has never, in this sense, been a lasting Latin American equivalent of 'Asian values', the 'Asian way' or the 'Asian model'. This is perhaps surprising given Latin America's historical ability to find itself as the testing ground for a number major policy experiments and theoretical contentions -modernisation theory, dependency and import substitution spring readily to mind. With neoliberalism, however, the Latin American region fell generally quickly into step with the globalisation process based on Anglo-American conceptions of capitalist development.

It is interesting, though, that despite the different experience of global crisis in the Asian region (as the first domino in the line) and the Latin America region (as some way further down it) and their very different starting points in terms of conceptions of capitalism, the unfolding outcomes in the light of recent events appear disconcertingly similar. As noted earlier, emerging economies have been tarred with the same brush by international financial markets and international investors, and as such the "crisis of confidence' has affected them equally. Reactions to emerging markets have become almost entirely informed by exercises such as credit rating and risk assessment by international banks and specialised agencies. From the time that the currency crises

\footnotetext{
33 See Weiss, The Myth of the Powerless State, and Suzanne Berger and Ronald Dore, National Diversity and Global Capitalism (Ithaca: Cornell, 1996).
} 
broke first in July 1997, the risk premiums for many such economies shot suddenly upwards. $^{34}$

Apart from the more immediate economic issues generated by the devaluations and currency crises, capital flight and falling growth rates consequent upon the collapse of confidence, the global and regional crises have unleashed a very similar process of questioning in both regions, and at first glance it appears that the longer term outcomes of this rethinking may well exhibit striking parallels in each region. This questioning revolves around the neoliberal globalisation paradigm as well as around the accommodation between regionalism and globalism and the governance of the international economy by the international financial institutions. Furthermore, even economists increasingly accept that the market turmoils in East Asia and their impacts in other regions since August 1997 are every bit as much political crises as they are economic ones. Indeed, the political implications of these events will linger long after the necessary economic reforms have been introduced to return at least a semblance of economic normalcy to the region.

\section{Rethinking International Policy Reform in East Asia and Latin America}

Notwithstanding the real, material explanations of the current global economic crisis, ideational explanations are fundamental. They reflect a western conceptual inability to deal with the failure of the Asian model of economic development to converge with an Anglo-American form of capitalism. Although the tension has been less clear in the Latin American case as a result of its greater convergence with the model or ideology in question, there has been a similar struggle on the part of Western governments and institutions to reconcile the vehemence of neoliberal reform on the one hand and the recurrence of economic difficulties in certain parts of the Latin American region on the other. These observations hearken back to arguments that even the financial institutions themselves were making at the start of the 1990s: that the failure of

34 ECLAC, The Impact of the Asian Crisis on Latin America, p. 19. 
structural adjustment in the 1980s could be traced to a neglect in the design of such programmes of political and institutional questions of domestic-level governance. The experiences of the global economic crisis, however, suggest that these acknowledgements in practical terms have led precisely nowhere.

IMF prescriptions for the Asian rescue drew on a western understanding of liberalisation, involving packages of domestic austerity and financial restructuring intended to cut demand and liquidity. As such, they were not new. They were tried and tested initially in Latin America and Africa where the principal economic ills were large budget deficits, high inflation and massively indebted public sectors. If the USA and the IMF have their way, then a western model of liberalisation, replacing the 'developmental state' model would come into place in Asia over time. Alternatively, it could also see a hardening nationalist resistance to neoliberalism. For what has been challenged in the crisis of the East Asian NIEs in the late twentieth century is the very model on which they have built their success. It should be seen not only as an economic crisis, but as a battle of 'ideas' or ideologies. Having 'won' the Cold War against Soviet style collectivism, no sooner is one bout of triumphalism over than liberalism is gleefully protesting its superiority over the 'developmental statist' approach towards capitalist economic development. The speeches of senior US policy makers and opinion formers have been peppered with references to the need to jettison the remaining vestiges of the developmental statist model. This does not play well in East Asia in short run. It may not play well in the long run either and can expect to fuel Asian resentment.

Regional economic trade liberalisation and financial de-regulation were the pay-off for a continued US security presence in the Asian region after the end of the Cold War. Those socio-political practices of the so-called Asian model that were acceptable for security reasons during the Cold War -- exclusionary politics, nepotism and the blurred lines of authority between political and economic power -- now clash more violently with the interests of private capital aggressively in search of greater and quicker profits in an era of deregulation. Indeed, the crisis, and especially the subsequent process of 
international financial institutional intervention, has exposed the ambivalent relationship that has always existed between the states of East Asia and the USA, and the US-led international institutions. As time has progresses, the nature of the bailout seems to become increasingly ambivalent and problematic for many Asian policy makers. They do not like it, but it is difficult to know what they would have done without it.

The initial roots of the turn-around in Latin American political economy from the midto late-1980s were in some ways similar. The debt crisis of the early 1980s and the experience of economic and political collapse in many countries (Argentina and Peru being the most obvious) generated a perception that change was inevitable. In order to generate the liquidity necessary to climb out of hyperinflation and stagnation, countries were constrained to build more constructive (and at times, in the words of Argentine Foreign Minister Di Tella, 'carnal') relationships with the US government, the international financial institutions and international investors. The availability of such funds was contingent on a wholesale adoption of the Western policy consensus, leading to processes of privatisation which in some countries were unparalleled in their speed and scope, unilateral trade and financial liberalisation and comprehensive economic restructuring. As with Asia, economic recovery depended on cooperation with US-led institutions and convergence with the US-sponsored conception of neoliberal globalisation.

The discomfort occasioned by such relationships, however, appears to have been greater among Asian policy elites than among their Latin American counterparts. This can be explained in part with reference to the existence of a quite well-defined Asian 'model' which, at the time, was the object of praise from the international financial institutions themselves. Another explanation would focus on the composition of the policy elites concerned with advancing the development project in the two regions. Government circles in both regions were populated by 'technocratic' policy makers which exhibited the characteristics of 'epistemic communities'. In Latin America, however, this 'community' was far more homogeneous than in Asia, and perhaps 
somewhat more fervently ideological in the early 1990s. Virtually without exception these individuals were educated in the United States, typically in Economics at Harvard or MIT, sometimes with subsequent posts in the international financial institutions. In Asia, on the other hand, the education of such individuals was in a much larger variety of countries, both inside the region (Japan, notably) and outside it. While 'classmate relations' amongst South Koreans educated in the US were strong, such socialisation experiences were not as significant in other badly affected Asian states such as Indonesia and Thailand, where overseas education was much more geographically dispersed. As such, the imported 'knowledge' would have assumed a more heterogeneous and, by extension, a much less fervently 'American' bent.

The burgeoning resentment of the international financial institutions' handling of the crisis in Asia, then, feeds off a well-established scepticism regarding western models and policy agents. On a practical level, the authority of the IMF would have been accepted more readily by the state policy elites of East Asia if the interventions had indeed rapidly restored market confidence and stability. But for many in the region -and not only Dr Mahathir -- the crisis appears rather to have presented the IMF with the opportunity to force open East Asian economies in two major ways. First, conditionality attached to the bailout packages has allowed, and will continue to allow, international banks to make major inroads into the regions banking sectors. There is mounting empirical evidence to support this argument. Second, 'liberalising' conditions, going beyond 'normal' macroeconomic targets, have paved the way for US firms to achieve unprecedented market access. Again, there is evidence to suggest that this is already happening. ${ }^{35}$

There is also widely held view in Asia that the financial markets have been driven by moral hazard' -- a lenders expectation that gains from risk taking will be private but

\footnotetext{
35 See for example Martin Khor, 'A Poor Grade for the IMF', The Far Eastern Economic Review, 15 January 1998, p. 29. Ted Bardecke, 'Roaring start to Thai fire sale', Financial Times, 26 June 1998, p. 17. Michael Koeneke, Chairman, Global Mergers and Acquisitions, Merrill Lynch, cited in International Herald Tribune, 20-21 June 1998, p. 5.
} 
losses incurred will be publicly borne. A double standard is perceived in the IMF insistence that regional governments not rescue local financial institutions while at the same time insisting that they guarantee the repayment of international loans, thus alleviating foreign lending houses from any 'moral hazard'. When coupled with Wade's Gestalt shift and the sheer volumes of capital outflow, moral hazard has done more to undermine confidence in global liberalisation since the Asian crisis than almost anything else. To the educated populations of the crisis-hit countries of the region this is seen as local entrepreneurs paying for their mistakes while the mistakes of foreign investors are underwritten at local expense. In short, IMF policies are seen in the region as designed to save western investors, not to save Asian economic development. As one Malaysian analyst noted:

What the rich could not do through bilateral and multilateral pressures, they are now extracting by using the IMF loans as leverage ... No wonder the IMF's main role in Asia is increasingly seen as chief debt collector for international banks. ${ }^{36}$

It is all well and good for western analysts to say that this is a partial reading of these processes. Perceptions matter in politics. That these perceptions are invariably ignored in the economic literature is because they can be neither modelled or quantified. Moreover, this, is not simply an Asian reading of events. As the Financial Times noted, those banks that lent money to Asia in profligate fashion were ' ... not just incompetent. They had reason to suppose that they would be repaid. Lend stupidly; act tough; and wait for the money to return. ${ }^{37}$ The banks that lent so freely have had to bear little of the cost of their policies. How to allocate wealth losses remains a key political problem emerging from the crisis, around which future policy adoption will turn. Almost all actors within the region are of the opinion that the policies advanced by the IMF have favoured the international investor at the expense of the domestic creditor. Moreover, it is argued by some that the strategies advanced -- especially an

\footnotetext{
36 Khor, 'A poor grade for the IMF', p.29

3710 June 1998, p. 29
} 
insistence on tighter monetary policies -- have worsened rather than enhanced the creditworthiness of indebted companies. ${ }^{38}$

The relationship with the IMF is slightly more ambiguous in Latin America than in Asia. On the one hand we can see certain elements of hostility to the agents of international finance, but this has not yet translated into the vilification of the international financial institutions that we can see in Asian responses. This may be due to a recognition of the indispensable nature of international assistance at the present time, but probably can be explained more readily with reference to the position of Latin America within the sphere of the 'West'. As such, the adoption of the Anglo-American model of capitalist globalisation may well have led nowhere near the expected stability and prosperity, but there is still a degree of attachment to the notion of insertion into the mainstream of Western, and global, economic activity. Anitpathy towards the IMF, and hostility to its methods, have for this reason been slightly more muted. Indeed, countries that see themselves to be a stronger position than their neighbours, notably Argentina, are clamouring to bring this to the attention of investors and institutions, and thus to serve as examples to countries like Brazil, Venezuela and Mexico that have once again run into serious trouble.

On the other hand, what Latin Americans do appear to be taking exception to is the dogged insistence of the US government, the international financial institutions and some neo-classical economists on the need for further neoliberal reform in order to shore up national economies against the current crisis. Claudio Loser (responsible for the Latin America and Caribbean section of the IMF) recently asserted, for example, that 'the Brazilians have always known what they have to do, and we have never had to tell them anything'. ${ }^{39}$ Recent problems with reform legislation in Argentina and Mexico, for instance, do not sit well with this orthodox prescriptive approach to overcoming present economic discomfort in Latin America. Attention, naturally, is

\footnotetext{
38 Stiglitz, 'Macroeconomic Dimensions of the East Asian Crisis', pp. 4-6.

39 Reported in 'Prevén pronto acuerdo de ayuda del FMI a Brasil', El Mercurio (Chile), 6 October 1998.
} 
focused on Brazil, seen as the flashpoint of the region and often compared to China in Asia. The present talks on the construction of an assistance package for Brazil -- or, more properly, for Latin America, of which at least half would be directed to Brazil -are premised on the assumption that the regional implications of a Brazilian collapse would be catastrophic. Although the funds made available would not, according to the IMF, be contingent on any specific quid pro quo in policy terms, Brazil would be obliged to sign an adjustment agreement with the IMF before such credit could be offered. The upshot, clearly, is the same.

Not much appears to have changed. The conceptual biases inherent in the IMF's treatment of Asia are already apparent in its emerging Latin American strategy, and the IMF certainly has not altered its approach in response to its experiences in Asia. What is needed, Latin Americans increasingly argue, is a novel approach to global financial and economic governance which displays flexibility and imagination -- 'intelligent solutions', in short, 'even if they don't feature in Economics books'. ${ }^{40}$ The present approach of the IMF and the US government departs almost not at all from the line they have been peddling for the last decade. This suits countries like Argentina and Chile that are relatively less threatened with collapse (except in the event of a repercussive Brazilian crisis), but appears to grate in countries that are currently struggling to tread water.

The implications of this for the global economy are precisely the opposite of what global liberalisers would wish for. Western political elites have under-estimated the influence of scapegoat explanations of the crisis within the Asian (and Latin American) region. In Asia, there is no deeply ingrained loyalty or cognitive belief in the market, and most Asians have only an instrumental feeling for the market. In Latin America also, resort to neoliberalism was generated only 'by default', and the social consequences of global neoliberalism at the domestic level appears to be steadily increasing the legitimacy and popularity of opposition currents which emphasise the 
‘democratisation' of market economics. What Linda Lim (ironically?) calls 'the lightly regulated' international financial markets stand in sharp contrast to the 'visible hand' that moves domestic markets in $\mathrm{Asia}^{41}$, and, furthermore, to the strengthening of state capacities which has paradoxically accompanied the internationalisation of Latin American economies. ${ }^{42}$

The treatment of East Asia and Latin America by the financial markets will have ambiguous results. While it may make states in both regions more responsive to 'market disciplines' in the short run, it may also in the longer run make them more suspicious of them. Certainly it will lead Asians and Latin Americans to prefer tighter rather than looser regulation of them, and not, it would seem, by the existing and in large part discredited international institutions as they are presently constituted.

The results of this 'rethinking' of the dominant policy paradigms is already evident. We have noted the growing calls for currency and exchange controls, and for restrictions on short-term capital flows, which have been made inside and (significantly) outside the two regions. Beyond short-term survival strategies, we are seeing the emergence of a genuine debate in domestic (and some international) policy circles, and in academic communities, on potential means of 'managing' or 'governing' globalisation. Evidence at present suggests that the future trajectory of policy will reflect an abandonment of the dogmatism of neoliberal discourse in favour of a more flexible and heterodox approach to economic management.

\footnotetext{
40 Mario Rodarte, 'El FMI en la crisis', El Economista (Mexico), 7 October 1998. Also see 'Hay que evitar el efecto contagio en la región', El Cronista (Argentina), 25 August 1998.

41 Linda Y. C. Lim, 'Crisis and Conspiracy', The Far Eastern Economic Review, 19 March 1998, p. 31.

42 See Nicola Phillips, 'Globalisation and the 'Paradox of State Power': Perspectives from Latin America', paper presented to the Annual Conference of the Society for Latin American Studies, Liverpool UK, 17-19 April 1998.
} 
The economic troubles have caused many Asian political leaders to rediscover the rhetoric of the popular nationalism as a way of deflecting domestic criticism. Across the most affected states a discourse of 'robbery', or a 'new imperialism', not heard since the years of the immediate post colonial era, is very strong. This is not only in Malaysia, where Prime Minister Mahathir has gone as far as to argue that western governments and financiers have deliberately punished Asia for its arrogance and refusal to converge more quickly towards a Anglo-American, liberal, approach to democracy, market opening, labour standards and human rights. Similar themes can also heard in Thailand, the Philippines, South Korea and Indonesia. In Latin America, the equivalent resurgence has been seen in populist rhetoric, or at least on debate about whether a return to populist economic strategies is warranted in view of the 'failure' of neoliberalism. ${ }^{43}$

As such, what we may be seeing is a trend away from 'automatic pilot' types of market strategy towards more active policies of the types enshrined in the Asian 'developmental state' model and advocated in Latin America by a growing number of governmental, societal and media voices. In contrast to a former adherence to the "no alternative' rhetoric of globalisation, there has been a flexibilisation of thinking at the regional and domestic levels. Policy debates indicate that it is no longer the case, as the neoliberal hard-liners of the early 90s would have it, that market strategies must be 'all or nothing', and that the converse is a return to inward-looking, state-led economic models. Rather, the impact of global economic crisis has created a space for the opinion that there are more than the traditional two economic policy agendas available to governments. ${ }^{44} \mathrm{~A}$ third would involve some sort of 'middle ground', in which the regulatory role of governments might be revitalised, greater attention might be given to social issues, and the emergence of a more 'national' or possibly 'regional' approach to economic management might be facilitated.

\footnotetext{
43 For example, Agustín Rodríguez Trejo, ‘'Es el momento de regresar al populismo?, Excelsior (Mexico), 8 October 1998.

${ }^{44}$ See, for example, Daniel Naszewski, 'Políticas activas versus piloto automático', El Cronista (Argentina), 18 August 1998.
} 


\section{The Articulation of Regional Responses?}

From the above we can argue that the Anglo-American model of neoliberal globalisation has been put on the block in two ways. First, its perceived 'failure' to generate economic stability and lasting growth in Latin America has led to the formulation (still in very preliminary stages) of alternative development strategies, ranging from modified policy agendas to more general reconsiderations of political and institutional structures. Although the Latin American region should not be seen by any means as an example of quintessential 'convergence', its approximation to policy along the lines of the Anglo-American model (especially in comparison with the Asian path) is sufficient for recent events to constitute a serious 'trial' of the model in this region. Second, the Asian crisis is a contest of ideology between Asian and Anglo-American ways of organising capitalist production. Alan Greenspan, of the US Federal Reserve Bank, has publicly argued that the crisis in East Asia's currency markets will have the effect of moving East Asian economic practice closer to that associated with the US model. ${ }^{45}$ For many Western analysts, the crisis (in its first phases at least) was a weapon in what they see as the normatively laudable process of achieving convergence. Only time will tell if Greenspan is correct or not. The strongest versions of this analysis ${ }^{46}$ suggest that the IMF is merely an instrument of US policy, doing Treasury Secretary Rubin's bidding in attempting to bring Asian economic policy making into line with the dominant approach of the US. One does not need even to accept this version, however, to recognise an important test of intellectual will is in train.

These dynamics, as well as unfolding responses in Latin America, suggest that the crisis may have unleashed a new type of 'regional' thinking, in which the identity and preferences of the East Asian or American 'regions' will increasingly be defined with

\footnotetext{
45 Alan Greenspan, speech to the Annual Convention of the Independent Bankers Association of America, 3 March 1998, http://bog.frb.fed.us/board/docs/speeches/19980303.htm

46 See Bello, 'East Asia: On the Eve of the Great Transformation?' and Jagdish Bhagwati 'The Capital Myth'.
} 
reference to external actors, notably the United States. Our argument here is built around a paradox. ${ }^{47}$ The global economic crisis has weakened the short-term desires of policy making elites in both regions to enhance regional economic cooperation. The exigencies of short-term survival strategies generate something of an 'atomisation' of policy responses as national states pursue policy measures in keeping with distinctively 'national' interests based on specific experiences of the crisis. This 'individualisation' of economic management leads to the relegation of regional issues and, in a more extreme case, to the fragmentation of any existing regional consensus. Conversely, a longer term perspective suggests a strengthening of regional conceptions of identity, which translate into a more closely defined and collective understanding of 'region'. This in turn strengthens political will to articulate a regional agenda, and particularly an agenda that is regionally distinct.

The desire for national decision making autonomy in the face of economic crisis thus is not incompatible with the longer-term articulation of a stronger collective regional understanding. In Asia, the result of experiences of states at the hands of the IMF doctors may well be the development of an 'East Asian' as opposed to 'Asia Pacific' understanding of region. This can be demonstrated by an observation of the limits of APEC after the crisis and the discussion of a putative Asian Monetary Fund (AMF). In Latin America, the juxtaposition is between a South American agenda constructed on the basis of an expanded Mercosur on the one hand, and the articulation of a hemispheric agenda through negotiations for a Free Trade Area of the Americas (FTAA) on the other. These cases offer evidence of a regional social learning from the crisis that may well give added momentum (once the immediate crisis has passed) to the process of greater economic policy coordination since the 1980s, especially given the apparent hostility of the United States to the articulation of such narrower definitions of regional interests.

\footnotetext{
47 See Nicola Phillips, 'Rethinking Regionalism: National Responses to Global Crisis in South America', paper presented to the Third Pan-European International Relations Conference and Joint Meeting with the International Studies Association, Vienna, 16-19 September 1998.
} 
Nowhere was this hostility better illustrated than in the US response to the regional initiative for an Asian Monetary Fund. Wall Street's concern was that an AMF style organisation would slow down the liberalisation of Asian financial markets. The US response to the crises, inherent in IMF policy, has been to liberalise trade, deregulate financial markets and enhance disclosure rules. All, by happy coincidence, coincide with the broader aims of US economic diplomacy in the region. More specifically, as the US Treasury has made clear all along, support for bail-outs, especially in Korea, was and is contingent on continued financial opening. Official US policy reflected this private sector desire for continued financial liberalisation. It also reflected a strong political and institutional desire not to cede the power of the US-dominated international financial institutions to regional institutions over which they would certainly have less ideological and practical control.

Viewed through American eyes then, a successful AMF was not consistent with overall American interests. It would have reinforced the trend, following the strengthening of the Yen from the time of the Plaza Accord through to the first half of the 1990s, of the Japanese replacement of the US as the major source of FDI, the major force for production and principal aid donor in the region. ${ }^{48}$ With hindsight, US fears that an AMF would have weakened their hold over the policy process in Asia, especially vis-àvis the Japanese, appear grossly overstated: the AMF was never viewed by the Japanese as a competitor to the IMF, although it may have been by others such as Dr Mahathir. However, such is the perversity of international politics that US opposition to the proposal may well mean a further attempt to initiate such a body -- in less frenetic times -- may become all the more inevitable.

Indeed, even in the teeth of the crisis, there is still considerable regional talk (and mostly talk, it must be said) about what form future regional (in this context meaning

\footnotetext{
48 See Walter Hatch and Kuzo Yamamura, Asia in Japan's Embrace, (Cambridge: Cambridge University Press, 1996) and Alan Rix, 'Japan and the Region: Leading From Behind', in Richard Higgott, Richard Leaver and John Ravenhill (eds.) Pacific Economic Relations in the 1990s: Cooperation or Conflict, (Sydney: Allen and Unwin, 1993).
} 
East Asian) policy to enhance economic surveillance and cooperation might take. ${ }^{49}$ Crucially, this talk is taking place in an East Asian context rather than an Asia Pacific context. The opposition of the US to the proposal for a specifically Asian regional fund sowed (more) seeds of polarisation in the relationship between the Asian and Caucasian members of APEC. Subsequent arguments about the role that the IMF should play in the rescues in the region, especially in Indonesia and South Korea, were only resolved in favour of the IMF taking the lead role after considerable argument at the 1997 Vancouver APEC Summit. The exhortatory liberalisation rhetoric of the Vancouver APEC only superficially concealed a deeper schism between the two edges of the Pacific. The economic turmoil reinforced the notion that the Asia Pacific is an artificial construction of region, the long term salience of which may well have been affected by the economic downturn, or more specifically by the prospect of longer term regional resentment at the US and IMF led responses to the crisis.

It is now clear that the euphoric expectation of the 1993-6 period that APEC would provide firm institutional ties to mitigate inter-regional tensions between Asia and the US was wishful thinking of a high order. But the real loser in the ideas battle that has developed out of the crisis is the notion of regionalism embodied in APEC. APEC endorsed a standard model of macro-economic policy reform, with all the accompanying implications of painful restructuring processes for most countries of the region. Advocates of APEC, concentrating on the liberalisation of the trade regime, championed 'open liberalism' in the region assuming that it was benign, beneficial and its enhancement largely uncontested. Much of the discussion on APEC saw only the benefits and none of the potential pitfalls of the dramatic increases in deregulated, unrestricted capital mobility. ${ }^{50}$ APEC always found its strongest intellectual and

\footnotetext{
49 This is discussed extensively in Higgott, 'The Asian Economic Crisis'.

50 This excessively optimistic view of APEC abounded within the trans-regional policy communities of the region. See for example, C. Fred Bergsten, 'APEC and World Trade', Foreign Affairs, May/June 1994, pp. 20-26; Peter Drysdale and Ross Garnaut 'A Pacific Free Trade Area? A General Theory of Economic Integration', in C. Fred Bergsten and Marcus Nolan (eds.) Pacific Dynamism and the International Economic System, (Washington D.C.: Institute for International Economics, 1993); Ross Garnaut and Peter Drysdale (eds.) Asia Pacific Regionalism: Readings in International Economic Relations, (London: Harper Collins International, 1994) and Ross Garnaut, Open Regionalism and Trade Liberalisation: An Asia Pacific Contribution to the World Trade System, (London: Routledge, 1997). The optimistic view is challenged in Richard Higgott, 'APEC: A
} 
political support amongst its American, Australian and Canadian members. During the heyday of Asia Pacific growth, the Asian members were willing to go along with its emerging programme, although not necessarily at the pace the Caucasian members wished. ${ }^{51}$ In the post-crisis era things have changed considerably. APEC, rather than being a potential instrument for trade liberalisation at the Asia Pacific level in which a harmony of interest developed between the member states, is now seen in East Asia as but an additional site at which the US can hammer home a Wall Street-Treasury approach to further capital market liberalisation.

There have been no proposals as yet for a Latin American equivalent of the AMF. There is a certain argument to be made that the fortunes of the Latin American region is tied more closely in institutional terms to the United States, if only for geographical reasons in a regionalising world. Nevertheless, recent developments in the prospective construction of a hemispheric bloc point to some similar dynamics at play in the articulation of regional identities and agendas. Regional cooperation / integration in Latin America, as in Asia, was intended to produce the 'regionalisation' of a standard set of policy goals based on liberalisation. The onslaught of the global crisis, however, has pulled the rug from under these conceptual underpinnings of regionalism. The revision of key policy assumptions examined in the previous section of this paper has clear implications for the regional project.

The spate of collective action seen in frenetic summitry between Latin American countries and the IMF and US government, the bail-out package for Brazil, the Latin American assistance package to Venezuela, and more general calls for 24-hour hotlines between Latin American presidents ${ }^{52}$ only thinly disguises the increased divergence between countries in their responses to the Asian and global crises. Countries have been hastily trying to distance themselves from each other - particularly Argentina from

Sceptical View', in Andrew Mack and John Ravenhill (eds.) Pacific Cooperation: Building Economic and Security Regimes in the Asia Pacific, (Sydney: Allen and Unwin, 1994.)

51 See Nicole Gallant. and Richard Stubbs, 'APEC's Dilemmas: Institution Building Around the Pacific Rim', Pacific Affairs, 70 (2) 1996. 
Brazil and, to a lesser extent, from Mexico. ${ }^{53}$ Immediate policy responses, furthermore, have demonstrated a tendency towards divergence as governments pursue measures appropriate to the economic structures and conditions, as well as the political climate, of the country in question. This has resulted in the relegation of regional issues (such as the consolidation of the Mercosur) at least temporarily as countries engage in activities designed to avoid economic collapse or else mitigate the worst effects of devaluation. The present negotiations on a potential FTAA ${ }^{54}$, however, cast a new light on these developments at the sub-regional level.

Hemispheric integration is at present secondary to the development of sub-regional units, and the bilateral deals that countries are pursuing increasingly vigorously. These 'spoke-spoke' 55 arrangements are already seen as important ways in which the South American contingent led by Brazil has acted to counter the weight of the United States. It was Brazil, with probably the least pronounced interest in the regional market, that called in 1994 for the formation of a South American Free Trade Area (SAFTA) in order to conduct negotiations for wider regional integration with the US, as an alternative to the US's preferred country-by-country basis. ${ }^{56}$ The global crisis is likely, in the longer term, to strengthen the southern countries' desire to negotiate as a coherent bloc rather than as spokes around a hub. If the crisis has the effect of further increasing the defensive nature of southern regionalism, as well as altering the policy tenets on which it is based, these divergences between north and south will become more pronounced. It is entirely probable that some kind of hemispheric cooperation will be constructed, but this is most likely to be in the 'shallow' form of reciprocal trade arrangements rather than a 'region' of the Americas.

52 See El Cronista (Argentina), 25 August 1998.

53 'La Argentina comenzó a poner distancia del socio brasileño', and 'Una buena señal a los mercados para tratar de diferenciarse', El Cronista (Argentina), 4 October 1998.

54 For an overview, see Paulo S. Wrobel, 'A Free Trade Area of the Americas in 2005?', International Affairs, 74 (3) 1998: 547-61.

55 Stephan Haggard, 'The Political Economy of Regionalism in Asia and the Americas' in Edward D. Mansfield and Helen V. Milner (eds.), The Political Economy of Regionalism (New York: Columbia University Press, 1997), p. 41.

56 La Nación (Argentina), 22 April 1998. 
As such, it appears that there is still a genuine political will to construct a region in Latin America, but this is defined predominantly in terms of a power struggle, however benign, between the northern and southern hegemons. Paradoxically, therefore, the initial divergence between the countries of the Mercosur may be diluted by the greater divergences between the north and south of the hemisphere in terms of macroeconomic policy and approaches to globalisation. ${ }^{57}$ One of the main elements of the Mercosur that appears to be missing at present is the sense of a genuine regional identity beyond the economic bloc. The nascent lineaments of such an identity only emerge in the context of the relationship with the United States and NAFTA. This is not based on hostility or nationalist resentment (in contrast, perhaps, to the Asian region), but rather on a common perception that the Mercosur has established itself sufficiently to resist the possibility of being subsumed into a hemispheric scenario dominated by the United States. The upshot may be South American countries will propel themselves towards a more 'regional' understanding which inevitably would give impetus a greater degree of political cooperation between the member countries. Similar arguments about the prospects for East Asian regionalism after the crisis cannot be ruled out.

\section{(3) Convergence? What Convergence? Some Thoughts on the Future}

Whether Western analysts like it or not, then, explanations and interpretations of the crises in Asia and Latin America do not privilege the same factors as they do. Asians appreciate that there are flaws in their economic system that do not serve it well under contemporary capitalism. But uncontrollable movements of money are deemed to be as responsible for their current problems as the idiosyncrasies of Asian political and social systems. In the first wave of the crises, it was easier to target the problems of crony capitalism. But continued violent movements of capital in the second half of 1998, a full twelve months on, are causing more and more members of the Asian public and private sector policy making elite to resent the ineffectiveness and the inability of any existing international institutions to offer solutions other than to demand dramatic domestic structural adjustment within Asia. If Latin America does experience similar

57 These arguments are developed fully in Phillips, 'Rethinking Regionalism'. 
economic crises, a repetition of these kinds of trends in elite and public opinion seems likely.

Liberal economic internationalism is on trial in both Asia and Latin America, in both different and similar ways, at the end of the twentieth century. The crises, and Western responses to them, demonstrate the danger of interpreting Asian political and economic practice through western-elite images. These kind of analyses represent the unthinking assumption that the dynamics of globalisation -- including the globalisation of liberal political values -- will prove as attractive to Asian policy elites as they have done to Western policy elites. In so doing, the likelihood of 'convergence' around an idealised western system of economic management, political practice or an understanding of the culture of modernisation as a homogenising category is always going to be over-stated. There is some evidence of liberal influences finding their way into the elites of states such as Thailand, Korea and Taiwan. But the generalised assumptions of western policy elites that a convergence embodying universal interests which will create an Asia more like the liberal stereotypes -- more rational, more individualist, democratic, secular and concerned with human rights -- lack, as Robison and Goodman note, sound empirical foundations. ${ }^{58}$

The Asian crisis, contrary to triumphalist arguments, is not the vindication of the convergence hypothesis that much neo-classical economic analysis would like to assume. The crisis confirms the differences in systemic capitalist organisation rather than refute them. Asian leaders may parrot the language of neoliberalism within the context of APEC gatherings, but much of it is still opposed in practice. The feeling that there was an exploitative element in the Pacific economic relationship was never eradicated from fora such as APEC over the last decade. The nature of the IMF reform packages, and especially the overt 'power politics' manner in which they have been imposed, has brought a north-south divide back into the open in the relationship between the Caucasian and East Asian members of APEC. 
The 'trial' of liberal economic internationalism in Latin America runs along slightly different lines. It concerns the instrumental value of liberalisation and participation in global financial and economic activity, but does not, for obvious geographical and institutional reasons, constitute a battle of intellectual or ideological wills of the type that we see in Asia. Nevertheless, the experience of the current global crisis has focused attention on the characteristics of contemporary Latin American (as opposed to Western or hemispheric) political economy. Dynamics in the regionalisation process, as we have shown, are likely to strengthen the trend towards an articulation of a regional 'identity' informed by political, institutional and socio-economic realities rather than by an adherence to a generalised, globalised, set of values and policy prescriptions.

One of the main effects of the crisis, in this light, has been to 'downsize' of the economic status of the Asian states and to throw cold water on the neoliberal 'triumphs' of the Latin American region. All of a sudden, the discourse of the 'miracle NICs' and the 'miracle' economies of Latin America has been re-constituted in favour of a 'Third World', 'us-them', 'haves-haves not', neo-dependency discourse not too dissimilar to that which prevailed in the 1970s when a call for a New International Economic Order dominated north-south relations. In Latin America, perceptions of the 'failure' of neoliberalism have prompted echoes in some quarters of pre-globalisation, pre-reform arguments that Latin American and other emerging markets are either not ready, or else not suited, for liberal economic internationalism. ${ }^{59}$

Such reactions give rise to resentment and resistance, most obviously at present in Asia. This seems to be occurring not only within the domestic polities and societies of

\footnotetext{
58 Richard Robison and David Goodman (eds.) The New Rich in Asia: Mobile Phones, MacDonalds and Middle Class Revolution (London: Routledge, 1996), pp. 2-3.

59 For example, 'Peter Belohlavek: La globalización es una realidad lejana para Venezuela', El Nacional (Venezuela), 8 October 1998; José de Jesús García, 'No aptos para la globalización: países emergentes', Excelsior (Mexico), 7 October 1998.
} 
the region -- where 'mass politics with a class edge' is set to make a comeback ${ }^{60}$-- but also at the level of the trans-regional policy making communities that had supposedly been making strides towards greater economic dialogue and harmonisation of economic policy across the Asia Pacific within bodies such as APEC. The crisis demonstrated the limits of APEC. As a body capable of making decisions of regional utility it was paralysed by the crisis. The US drove through the IMF reform packages at the Vancouver Summit. In so doing, the crisis has widened the gap across the Pacific and made the inherent tensions more transparent. As a consequence, putative regional economic cooperation -- through groupings like the East Asia Economic Caucus (EAEC) and the exploration of regional monetary cooperation -- may prove more conducive to the longer term interests of regional policy elites than APEC.

The development of Latin American political economy demonstrates broadly similar trends. The global crisis is likely, once the immediate policy responses have been made, to have exacerbated an existing trend towards the rearticulation of civil society after the period of neopopulist exclusionary politics which characterised the early 1990s. As such, the crisis is likely to propel further the process of questioning which involves most notably the nature of the economic model and the political environment in which it is pursued. These trends already point in the direction of the formulation of a less orthodox approach to economic management, and therefore a policy course which deviates more or less significantly from the pure Anglo-American model of liberal economic internationalism. This will have important implications for the regional project, which, in the long term, may well be the level at which an alternative agenda is most actively designed and consolidated. Growing distance between North and South America in the context of the global crisis is likely to give an added 'regional' flavour to this process of rethinking.

Competing views of how to manage the regional economic order are delicately balanced. For many of the regions' policy communities the crisis confirms the dangers of too much economic liberalisation. Policy elites may not have solutions, but it is clear

60 Bello, 'East Asia: On the Eve of the Great Transformation?', p. 442 
to them that there is a problem with the management of the international economic system. We do not have a functioning system of multi-level governance, nor do we have any longer a hegemonic one. The role of the US is vital but it is not still hegemonic in the manner envisaged by hegemonic stability theory (HST), and calls for a reassessment. It is in the Asian region that this reassessment will be most acute. Similarly, the eventual structure of relations between North and South American 'regions' will perhaps have the effect of evening out (to an extent) asymmetries of power in the Western hemisphere, as Brazil leads a strengthening and expansion of the South American agenda. The period since the end of the Cold War, and even more since the beginning of the crisis in Asia, has resonated with triumphalism. HST has given way to HRT (Hegemonic Replacement Therapy).

To Asian leaders it appears that no one is in charge of the financial markets. This lack of order does not sit well with them. Notwithstanding the recent intellectual battering of the 'Asian Way' in the international media (especially The Economist and the International Herald Tribune), Asia's greater permissiveness toward state intervention may not have yet run its course. We may see Asian governmental structures becoming leaner, more transparent and less receptive to rent-seeking behaviour and cronyism, but it is unlikely that all elements of the 'developmental statist' model will be torn up in the interests of a purer Anglo-American neoliberalism.

Anglo-American neoliberalism, similarly, is not likely to be torn up entirely in Latin America. Rather, new currents in official opposition circles, and also in public opinion, emphasise the maintenance of the policy fundamentals of a market economy, but focus on 'socialising' or 'democratising' the economic model. Crucially, the legitimacy of a broadly market-oriented economic strategy is vastly assisted by the disastrous experiences of Latin American countries with various alternatives. It is hard to argue, even for those opposed to the neoliberal policy agenda, and even in the context of the present global crisis, that Latin America is not in far better shape now than it was at the start of the 1980s. As such, issues for the next generation of governments will centre on the democratisation of the state, accountability, transparency, social policy, 
unemployment, education, and so on -- in effect, on the role of governments and states in regulating global and domestic markets, and in mitigating the worst aspects of their socially deleterious impact.

What the Asian crisis and subsequent events in other regions tell us, though, is that there is no consensus on how to manage international capitalism in the closing stages of the twentieth century. The major financial institutions are caught between nationalists and liberals with competing views of how the world should work. These institutions have proved leaden footed by comparison with the speed at which markets operate. The IFIs have been found wanting in both theory and practice by the events in East Asia. At the most basic levels, such as economic surveillance, the IMF has been inadequate. This was especially the case in Korea and Indonesia, if less so in Thailand. Policy advice on structural reform to the financial system has been inadequate, intrusive, often wrong and raises questions about the legitimate role of the international institutions. In short, the IMF programmes have had only limited success, and aspects of them have undoubtedly enhanced the sense of panic within countries and, by making real incursions in to the sovereign autonomy of the political processes of several countries (for better or worse), they have generated long-lasting resentment.

Globalisation requires the development of institutional capability for prudential regulation of private cross-border flows, especially of FDI to developing countries. If not, speculative portfolio capital will continue to wing its way around the world as part of the under-regulated global competitive game. While most policy analysts recognise regulation -- or more appropriately, re-regulation -- is best pursued at the global level, regional-level initiatives will evolve of the type outlined in the Manila framework and in the discussion of an Asian Monetary Fund or an enhanced collective identity in South America. In a post-hegemonic era there is no 'lender of last resort'. Latin American and Asian policy elites -- those on the way out and those on the way in -will have learned that they must look to self help at the regional level as much as to the institutional resolution of these issues at the global level. 
At this global level, regulatory complexity and the problems of the management of international financial markets, monetary relations and trade policy remain key questions for all governments at the close of the twentieth century. Some rules, norms and institutions for the management of some aspects of globalisation exist, but they are not sovereign. The Bretton Woods framework that emerged under American hegemony has long since unravelled. ${ }^{61}$ If a traditional division of labour has seen the IMF responsible for macroeconomic advice and the World Bank responsible for microeconomic advice then such a dichotomy -- or, more accurately, inter-institutional policy contest -- has become dysfunctional when looking at banking and finance in an era of deregulation. Given the nature of bureaucratic politics at work in the two institutions, it is unlikely that closer cooperation will come about easily.

Finally, one way in which the crisis might be, to use Camdessus's expression, 'a blessing in disguise' is in the way that it begins to unravel the myopia of economic theory when it comes to politico-psychological factors in explaining international economic order and disorder. The IMF would now appear to have the message that in order for governments to implement its policies it needs not only credibility with the financial markets but also the popular support of the key elements in a country's civil society. By not seeing the importance of this issue the IMF has almost systematically belittled every government to which it has extended financial assistance, with obvious implications for the standing of government. The photograph of Camdessus standing, arms folded, looking over Suharto's shoulder while he signed the rescue agreement is indelibly printed on the mind of most Indonesians. This is not an argument in favour of easier conditionality or tolerance of corrupt practices where they are known to exist. Rather, it is to recognise that liquidity squeezes -- the essence of most IMF packages -are highly sensitive, often very humiliating exercises for the recipients. The manner in which they are administered are as important as the substance of the agreement. The IMF's bedside manner, perhaps more than anything else, has detracted from its credibility in Asia and, perhaps to a lesser extent, Latin America.

61 See Ruggie, 'At home abroad, abroad at home'. 
What kind of new institutions would these be? The biggest institutional loser in the current crisis round has been the IMF. It has tried to present itself as a neutral and disinterested party disbursing rational adjustment policy recommendations to crisis-hit emerging market economies in a manner similar to which a GP dishes out prescriptions to flu victims. Unfortunately, the analogy no longer holds. The period since the outbreak of the crisis in Asia, and especially the last 12 months, has seen the IMF become much more acquiescent in policy terms towards the wishes of the US policy community. Its location in Washington means that it is acutely sensitive to its unpopularity in the Republican dominated US Congress. While its ideological sympathies with the policy line emanating from the Clinton administration, driven by economists such as Rubin and Summers would exist anyway, it needs US contributions, none of which would be forthcoming without Congressional approval. The effect of this has been that it has had to administer formulaic, essentially laissezfaire, prognoses and policies for troubled emerging markets rather than pay more attention to national cultural, historical, institutional and political circumstances. There is no political theory and even less appreciation of diverse political practice at the IMF to accompany its orthodox and inflexible economic prescription.

The next decade will be one of contest. We can expect it to be one in which the free market fundamentalism of the previous decade gives way to the growing recognition of the need to create global institutions capable of securing greater stability in the system than it exhibits at present. At a practical level governments of a more interventionist flavour now occupy centre stage in Europe and the US than was the case throughout the 1980s and early 1990s. They have all to some extent signalled the need, if not to put the deregulated financial market genie back into the bottle, then at least to instil into that genie a set of behavioural norms by which to operate. Furthermore, there is much greater cognisance of the need to create a set of institutions more oriented to controlling the genie in an era in which technological advance has made the need for new systems of observation, regulation and policy harmonisation all the more salient. 
